This item was submitted to Loughborough's Research Repository by the author.

Items in Figshare are protected by copyright, with all rights reserved, unless otherwise indicated.

\title{
Housing mix, school mix: barriers to success
}

PLEASE CITE THE PUBLISHED VERSION

http://dx.doi.org/10.1080/02680939.2013.783933

\section{PUBLISHER}

(c) Taylor \& Francis

\section{VERSION}

AM (Accepted Manuscript)

\section{PUBLISHER STATEMENT}

This work is made available according to the conditions of the Creative Commons Attribution-NonCommercialNoDerivatives 4.0 International (CC BY-NC-ND 4.0) licence. Full details of this licence are available at: https://creativecommons.org/licenses/by-nc-nd/4.0/

\section{LICENCE}

CC BY-NC-ND 4.0

\section{REPOSITORY RECORD}

Camina, Margaret M., and Paola lannone. 2019. "Housing Mix, School Mix: Barriers to Success". figshare. https://hdl.handle.net/2134/25340. 
Camina, M. and Iannone, P. (2014). Housing mix, school mix: barriers to success. Journal of Education Policy. 29(1), 19-43.

\title{
Housing Mix, School Mix: Barriers to Success
}

\section{M.M. Camina and P. Iannone}

School of Education and Lifelong Learning, University of East Anglia, Norwich NR4 7TJ England.

Corresponding author: m.camina@uea.ac.uk

Postal details: 3 Barnes Yard, Leonards Street, Norwich, NR3 3DR.

\begin{abstract}
.
Recent UK policy has emphasised both the development of socially mixed communities and the creation of balanced school intakes. In this paper, we use a case study of an area of mixed tenure in eastern England to explore policy in practice and the extent to which mechanisms of segregation impact on both the creation of socially mixed neighbourhoods and socially mixed schools. We draw on parent and pupil views of schools, combined with local authority data and geo-demographic classification to explore the background to school destinations. Overall, we find different expectations underlying the two strands of policy and show how a more detailed understanding of context helps those supporting or judging schools.
\end{abstract}

\section{Keywords}

School 'choice' / school context / mixed neighbourhoods / social class 
Camina, M. and Iannone, P. (2014). Housing mix, school mix: barriers to success. Journal of Education Policy. 29(1), 19-43.

\section{Introduction}

There is continuing international interest in the social segregation of schooling, particularly for those who see it as an on-going source of unfairness and a potential threat to social cohesion. The recent study by Coldron, Cripps and Shipton (2010) provides a comprehensive summary of the situation in England and of the body of research that has examined the statistical evidence on segregation and the underlying processes, such as the strategies and mechanisms of choice and the marketization of education. What may be less well-known among an audience familiar with the educational research is that there is also an international body of work on residential segregation and the potential for residential mix and residential mixing (Goetz 2002; Norris 2006; Wood 2003). This paper seeks to examine housing and schooling together and to do this from a local perspective. By selecting a case study approach and choosing a suburban setting in eastern England, the investigation adds to and contrasts with the well-documented accounts of the process of school choice in the inner city and it looks beyond poverty (in the UK, typically measured by eligibility for or take-up of Free School Meals) to the more nuanced aspects of segregation revealed by the proprietary geodemographic MOSAIC classification system. Because this area has been under the spot-light for several decades, it also illustrates the way in which reputation and choice vary over time.

Our case-study, a suburb which we will call Fairview, originated in the mid-nineteenseventies and was planned from the outset to be a mixed community, with the aim of attracting all sections of society (Fairview ${ }^{1}$ Council, 1974). Provision was made on the estate for primary schooling, with two schools serving the youngest pupils. We name

\footnotetext{
${ }^{1}$ To preserve anonymity, the pseudonym 'Fairview' has also been used for the publication reference.
} 
Camina, M. and Iannone, P. (2014). Housing mix, school mix: barriers to success. Journal of Education Policy. 29(1), 19-43.

them Meadowbank Infants and Weston Infants to reflect the part of the estate where they are located, Meadowbank serving the oldest part of the estate. These names also reflect their current status of taking pupils from the year in which they become five, the start of compulsory schooling (Year 0 ), until the year in which they become seven (Year 2). (For much of the period examined, they were 'First Schools', with the children staying for an additional year.) There was a single school for the next stage of primary education, Weston Juniors, adjacent to Weston Infants. It currently caters for children from Years 3 to 6 and was formerly a Middle School for Years 4 to 7 . The secondary school options (named here as Norton, Elmham, Treetops and Hawthorns) are all off the estate. The Local Education Authority, at the time the estate was planned, expected Fairview pupils to have an equal chance of attending the school of their choice as all other pupils in its area.

The specific research questions addressed are:

- In what ways do attitudes to school and to choice in this suburban setting reflect the patterns identified in previous research?

- Have education admission arrangements and expressions of parental choice created socially mixed schools to serve this mixed community?

We first set the scene in terms of policy and research findings, looking at both housing and education, as well as work which brings housing and education together. Current thinking on class is also crucial, as this underlies both housing and educational choices. We next consider the methodological approach and then describe the setting in terms of tenure and social composition. In the following section we present our data regarding school choice and school destinations at both primary and secondary level. A 
Camina, M. and Iannone, P. (2014). Housing mix, school mix: barriers to success. Journal of Education Policy. 29(1), 19-43.

discussion of the class basis for school preferences follows, noting how our case study, a largely white, suburban, community, compares with the more frequently studied inner city communities. The conclusion considers the policy implications of the findings.

\section{The Policy Framework and the Research Debates}

Contemporary interest in mixed tenure neighbourhoods in the UK stems from the 1970s and the official recognition of the problems arising in large areas of social housing. There have been strong criticisms among both housing and educational experts of attempts to regenerate such areas by 'inserting' areas of new middle-class housing into established estates (Graham et al. 2009; Lupton and Tunstall 2008; Lipman 2008.) This paper however focuses on the creation of such neighbourhoods from scratch as reflected in the policy of previous and current UK governments. Current planning policy expects new developments in all areas, urban and rural, to be "sustainable, inclusive, mixed communities" created by including "a variety of housing, particularly in terms of tenure and price" (Communities and Local Government 2010, 6 and 9). While planning powers can exercise some influence on the range of housing provided, the use of tenure remains a blunt tool and researchers have raised doubts about its effectiveness (Rowlands, Murie and Tice 2006; Tunstall 2003). The identified benefits stemming from such policies include the potential for higher quality services being attracted into the areas and the reduced likelihood for residents to be stigmatised by their postcode, for example, when applying for jobs (Buck 2001; Kearns and Parkinson 2001; Turok, Kearns and Goodlad 1999). Several reports commissioned by the Joseph Rowntree Foundation show that, with good design, such neighbourhoods are popular with both owners and renters and provide a 
Camina, M. and Iannone, P. (2014). Housing mix, school mix: barriers to success. Journal of Education Policy. 29(1), 19-43.

way of reducing the social exclusion and concentrations of poverty and unemployment which can arise in large areas of social housing (Allen et al. 2005; Rowlands, Murie and Tice 2006; Silverman, Lupton and Fenton 2005).

It should not be assumed that social mix leads to social mixing, rather that these are civilized communities where relations between owners and renters are polite, albeit rather distant. Because there is limited social interaction, Allen et al. (2005) cast doubt on the potential for two of the previously assumed benefits, i.e. the passing on of know-how and the role-model effect, but their research (p35-36) acknowledges a different situation for children, where there is closer social mixing than for adults. Other work indicates the possibility of role model effects, based on observation of different life-styles rather than on close social contact, with examples citing changes in parenting practices (Camina and Wood 2009; Rosenbaum, Reynolds and DeLuca 2002).

While housing and planning professionals have attempted to create socially mixed neighbourhoods, educationalists have sought to create socially mixed schools in the interests of reducing social class inequalities and promoting better attainment overall (Benn and Chitty 1996; Lauder and Hughes 1990; Willms 1992). However, there is no overall consensus on the effects of school composition and, while providing a comprehensive review of the extensive body of international research on the extent to which both school compositional effects and neighbourhood effects influence pupil attainment, Thrupp, Lauder and Robinson (2002) show how difficult it is to reach firm conclusions in view of the complexity of the processes and the difficulties of measurement. More recent work in the UK includes Noden and West (2009) on the 
Camina, M. and Iannone, P. (2014). Housing mix, school mix: barriers to success. Journal of Education Policy. 29(1), 19-43.

attainment of poorer pupils according to the level of deprivation among the intake as a whole. As in the housing sphere, social mix does not automatically lead to social mixing as in-school factors such as setting and subject choice can serve to institutionalize social differences (Araujo 2007; Davies et al. 2008).

In terms of admissions, England has tended to occupy a position between the choice driven North American model and the geographically driven European model (Butler and Hamnett 2007). The recent policy emphasis has been mainly on achieving fair admission procedures and the introduction of an English School Admissions Code in 1999 and subsequent amendments have in fact produced changes to admission policies and to the social composition of particular schools. For the period of their study (2001/2 to 2009/10), Allen et al. (2012) found that school segregation declined a little when the regulations were tightened. Nevertheless, 'parental choice' dominates the political agenda and researchers have highlighted the drawbacks of a focus on choice, given that this is a complex process, with a strong class difference in approach and severe practical constraints on choice for many families (Ball and Vincent, 1998; Butler and Hamnett 2010; Gewirtz, Ball and Bow 1995; Reay and Lucy 2003; West, Noden and Edge 1998).

\section{Residential Segregation and the Re-thinking of Class}

Coldron, Cripps and Shipton (2010) explore the extent to which residential segregation can be considered to be a cause of school segregation and conclude that it is the factors behind choice of residence and choice of school which link the two forms of segregation. Undoubtedly in some situations buying a house is effectively buying a place at a particular school (Butler and Hamnett 2010; Croft 2004; Holme 2002). 
Camina, M. and Iannone, P. (2014). Housing mix, school mix: barriers to success. Journal of Education Policy. 29(1), 19-43.

Cheshire and Sheppard (2004) have, however, shown that purchasing behaviour takes into account secondary schools (but rarely primary), that only the best schools attract a house price premium and that it depends crucially on local admission policies.

Choice of housing is now much more prominent in discussions of class than it was prior to the 1990s. Drawing on Bourdieu's development of the concepts of 'habitus', 'culture' and 'identity', lifestyle and cultural practices are seen as increasingly relevant in defining and understanding class (Bourdieu, 1984; Devine et al 2005; Skeggs 2004). Savage et al. (1992) used consumption patterns to identify three distinct middle class groups: public sector welfare professionals, private sector professionals/specialists and managers/government bureaucrats. These differences are not simply based on patterns of occupation and employment. Particularly (but not exclusively) among the middle classes, cultural and economic assets are invested in housing, distinctive choices are made and being part of the chosen community reinforces class characteristics.

\section{Methodology}

This being a case study, the first step was to acquire an understanding of the area, its housing and its schooling, (Yin 2002) using Census data, council documents and maps, together with a wealth of archive material, notably information for parents on school admission arrangements (1977 and 1983- 2008) and a monthly newsletter circulated throughout the estate since the 1970s. Data on published examination results and the public reports on schools produced by the national Office for Standards in Education, Children's Services and Skills (OFSTED) were also collected as background to the 
Camina, M. and Iannone, P. (2014). Housing mix, school mix: barriers to success. Journal of Education Policy. 29(1), 19-43.

local reputations of the schools. This body was created in 1992 and each of the schools described had been inspected three or four times by 2008. As well as assessments on different subject areas, overall assessments have been made on a 4-point scale: 1 (Outstanding), 2 (Good), 3 (Satisfactory) and 4 (Inadequate). Following this, a school may be placed in special measures if the inspectors decide that it does not have the capacity to improve without additional help.

To probe local views on school reputation and school choice, data was drawn from interviews held in 2004 and 2008, commencing with semi-structured interviews with long-term residents active in the community, including former school governors, (8), with parents of pre-school children in one of the pre-school settings (4) and with local professionals (14), including the head teachers of the three neighbourhood schools. Other parents willing to talk about their estate and the schools had responded to a mailing of 500 sample households and participated in one of two focus groups (owners or renters). Specifically, it was seen as valuable to explore children's views of the choices involved, as they are most directly affected, accepting with Reay and Lucey (2003:122) that their interpretations of the process draws "on both adult and peergenerated discourses in order to make sense of (it)". They are not necessarily reflecting the views of their parents. Focus groups were held in each of the schools involving a total of 16 pupils mainly age eight (at that time, the age of transfer from the First to Middle schools), 24 age ten and part way through the Middle school and (in the second phase) 15 age eleven who knew which Secondary school they would be going to. (By this time there had been a change in the system locally and this transfer took place a year earlier, coming into line with the national norm.) Photos of schools and other features of the estate were used to stimulate comments (Kamberelis and 
Camina, M. and Iannone, P. (2014). Housing mix, school mix: barriers to success. Journal of Education Policy. 29(1), 19-43.

Dimitriadis 2005). All focus group sessions and interviews were tape recorded, transcribed and analysed to establish key themes. Particular note was made of the time period referred to and of the place of residence of the participant. Children were asked to provide their post-codes as they introduced themselves. (See below).

In order that we could assemble a long-term record of the school destinations of Fairview pupils, the Local Authority (LA) made available to us an extract from their computerised pupil records so that we could trace back the schools attended by Fairview pupils, without compromising the anonymity of pupils. These data provided good coverage for 19 year-groups of pupils starting school from September 1989 to September 2007, with an average of 98 pupils per year. For the four oldest yeargroups, only secondary school data were available. Because the analysis was to be based on socio-economic status, the pupils' post-codes were provided as well as their educational path-way. One limitation of this process was that these data could be extracted only on the basis of a pupil's most recent address and so those moving out of Fairview during their school career were excluded from the analysis and early data were missing where pupils moved into Fairview during their school years. Changes of address within the area could not be identified.

The analysis of the data centred on the relationship between social background and pupil destination and sought to use unique explanatory data rather than the more usual framework of eligibility for Free School Meals. Our choice of location offered a specific (and rare) advantage for analysis by tenure, in that the housing was laid out largely in single-tenure cul-de-sacs and a person's post-code therefore allowed immediate identification of whether the street was built for local authority tenants, 
Camina, M. and Iannone, P. (2014). Housing mix, school mix: barriers to success. Journal of Education Policy. 29(1), 19-43.

housing association tenants or for owner occupation. Out of a total of 130 post-codes on the estate, there were only 8 where original tenure was mixed and it was not possible to make this identification. (7\% of pupil addresses were affected.) Under a Government policy known as 'the Right to Buy', the tenure of the local authority culde-sacs has changed, with about $40 \%$ of the stock now owner-occupied, a consistent figure across the area but, typically, with the original tenants remaining in situ (Murie and Ferrari 2003). There is also now a small but unknown percentage of private renting, with buy-to-let properties to be found in both local authority and owneroccupied cul-de-sacs.

As a check on the validity of using tenure and as a way of exploring social background in more detail, a separate analysis was carried out using data from the MOSAIC postcode level neighbourhood classification system, a proprietary geodemographic product of the information service company Experian, kindly made available to the authors. School destination was examined in relation to the residents' behavioural types as described in the classification system. The databases included in such systems have been developed over the last twenty years and the data supplied in 2008 incorporated 2001 Census data and data derived from the Experian customer segmentation database, including lifestyle survey information, credit activity and house prices. Increasingly, the value of this kind of commercial data is being recognised by the academic community (Savage and Burrows, 2007; Webber, 2009). Its predictive success is in line with the research evidence described earlier that where people live is a better predictor of their behaviour than occupation (Singleton 2007; Webber 2004; Webber and Butler 2007). The practical advantages were that it was more up-to-date than the Census and that it provided a fine-grained classification, which was particularly useful 
Camina, M. and Iannone, P. (2014). Housing mix, school mix: barriers to success. Journal of Education Policy. 29(1), 19-43.

in this fine-grained mixed tenure area. Fairview's children came from ten of the sixtyone MOSAIC neighbourhood types. These fell into five of the eleven broad MOSAIC groups. (See Appendix 1).

\section{The suburban setting}

Nationally, the 1960s saw growing pressure for new housing, both to accommodate population growth and new household formation and to replace inadequate housing stock. In Fairview, a site which could accommodate 15,000 dwellings was available on the edge of the built-up area and the Council proposed to create a mixed-tenure development. In reaction to the large pre-war and post-war council estates, there would be 'pockets' of council housing. ${ }^{2}$ This was to be achieved by limiting land allocations to 2 hectare blocks, thus creating a patchwork of local authority, housing association and private housing, with the aim of avoiding the perceived 'stigma' of council housing. This development was not for any one section of society but for everyone. (Fairview Council, 1974.) The positive advantages of a social mix in schools was also a consideration with the possibility of a role model effect encapsulated in a comment by the then leader of the Council:

$$
\begin{aligned}
& \text { what we have to have is schools where some kids in every classroom have } \\
& \text { pianos in their sitting room. }
\end{aligned}
$$

The first phase of development adhered to these principles. Although the estate was generally described as 'half public, half private, the higher densities of housing in the

\footnotetext{
${ }^{2}$ Fairview Policy Committee 27.04.1972

3 Anecdote from a Committee discussion.
} 
Camina, M. and Iannone, P. (2014). Housing mix, school mix: barriers to success. Journal of Education Policy. 29(1), 19-43.

rented sector meant that $60 \%$ of homes in the first phase were built by the local authority. Overall, in spite of careful design and the Local Authority's ability to control the release of land, the evidence is that thirty years of changing housing markets and changing government policies made it difficult to sustain a balance of tenure across the estate, with the results shown in Table 1a . The Meadowbank Infants catchment now has a much lower proportion of owner-occupiers than its neighbour Weston Infants. Table $1 \mathrm{~b}$ confirms the distinction in terms of MOSAIC groups and Figure 1 illustrates diagrammatically the geographical mix of the main MOSAIC groups on the estate. Although there are relatively few groups represented, the fine grain of mix is distinctive, especially in Phase 1. (Note that Figure 1 includes Twilight Subsistence, housing catering for the elderly, which, not surprisingly barely featured among our pupils). The five MOSAIC groups into which our pupils' families fall are the following:

- Blue Collar Enterprise: by far the largest group - 51\% in Fairview compared to $11 \%$ nationally and spread throughout the estate. The Experian definitions suggest that this group comprises social renters and people who have purchased their council house but this is not always the case in Fairview. A number of the 'owner-occupier' cul-de-sacs, where houses were built for sale, house similar families to those in social housing and also come under this classification.

- Happy Families are most strongly represented in Phases 2 and 3. They account for $21.7 \%$ of Fairview pupils (double the UK average). They are typically younger people in newer homes, first generation owner occupiers and often with a high level of consumer debt. 
Camina, M. and Iannone, P. (2014). Housing mix, school mix: barriers to success. Journal of Education Policy. 29(1), 19-43.

\begin{tabular}{|l|c|c|c|c|}
\hline \multirow{2}{*}{$\begin{array}{c}\text { (a) Variation by tenure } \\
\text { \% owner occupation }\end{array}$} & $\begin{array}{c}\text { Phase 1 } \\
\text { Mid 1970s to } \\
\text { mid 1980s }\end{array}$ & $\begin{array}{c}\text { Phase 2 } \\
\text { Mid 1980s and } \\
2000 s\end{array}$ & $\begin{array}{c}\text { Phase 3 } \\
\text { Mainly post- } \\
2005\end{array}$ \\
\cline { 2 - 5 } & $\begin{array}{c}\text { Meadowbank } \\
\text { Catchment }\end{array}$ & & $\begin{array}{c}\text { Weston } \\
\text { Catchment }\end{array}$ & \\
\hline $\begin{array}{l}\text { 1991 Census } \\
\% \text { persons age 0-15 in owner } \\
\text { occupier households }\end{array}$ & $42 \%$ & $47 \%$ & $\begin{array}{c}\text { Combined } \\
\text { Phases 2+3 } \\
47 \%\end{array}$ & $0 \%{ }^{*}$ \\
\hline $\begin{array}{l}\text { 2001 Census } \\
\% \text { persons age 0-15 in owner } \\
\text { occupier households }\end{array}$ & $45 \%$ & $54 \%$ & $40 \%$ & $21 \%$ \\
\hline $\begin{array}{l}\text { 1998-2008 LA pupil database } \\
\% \text { pupils in owner-occupier } \\
\text { houses }\end{array}$ & $45 \%$ & $68 \%$ & $69 \%$ & $72 \%$ \\
\hline
\end{tabular}

* At this time only two small developments of social housing had been completed in Phase 3

^ Owner occupier cul-de-sacs plus LA housing cul-de-sacs adjusted for the Right to Buy

The boundaries used vary slightly for each Census and do not exactly cover Fairview.

The Census data is ONS Crown copyright reserved.

\begin{tabular}{|l|c|c|c|c|}
\hline \multicolumn{1}{|c|}{$\begin{array}{l}\text { (b) Variation by } \\
\text { MOSAIC group }\end{array}$} & $\begin{array}{c}\text { Phase 1 } \\
\text { Mid 1970s to } \\
\text { mid 1980s }\end{array}$ & $\begin{array}{c}\text { Phase 2 } \\
\text { Mid 1980s and } \\
2000 s\end{array}$ & \multicolumn{2}{|c|}{$\begin{array}{c}\text { Phase 3 } \\
\text { Mainly post- } \\
2005\end{array}$} \\
\cline { 2 - 5 } & $\begin{array}{c}\text { Meadowbank } \\
\text { Catchment }\end{array}$ & & $\begin{array}{c}\text { Weston } \\
\text { Catchment }\end{array}$ & \\
\hline Group B. Happy Families & $2 \%$ & $40 \%$ & $\begin{array}{c}\text { Combined } \\
\text { Phases 2+3 } \\
46 \%\end{array}$ & $54 \%$ \\
\hline Group D. Ties of Community & $18 \%$ & $10 \%$ & $6 \%$ & $0 \%$ \\
\hline $\begin{array}{l}\text { Group H. Blue Collar Enterprise } \\
\text { Group F. Welfare Borderline \& }\end{array}$ & $58 \%$ & $50 \%$ & $44 \%$ & $35 \%$ \\
\hline $\begin{array}{l}\text { Group G. Municipal } \\
\text { Dependency. }\end{array}$ & $22 \%$ & $0 \%$ & $4 \%$ & $11 \%$ \\
\hline
\end{tabular}

Source: 2008 Mosaic post-code data applied to pupil post-codes, 1998-2008 LA pupil database. See Appendix 1 for further explanation of the MOSAIC Groups.

Table 1. Fairview - social variation by building phase

- Ties of Community warrant further explanation. These owner-occupiers are the largest single group at the UK level, 16\% nationally, but less significant here at 12.1\%. The MOSAIC description which refers to inner-city, manufacturing and 
Camina, M. and Iannone, P. (2014). Housing mix, school mix: barriers to success. Journal of Education Policy. 29(1), 19-43.

nineteenth century terraces is not appropriate but other characteristics are

relevant - the affordability of the housing, close-knit family groups and an

emphasis on manual occupations. The majority of these households are owner-

occupiers living in Meadowbank.

- Welfare Borderline and Municipal Dependency feature more strongly in Phase

1 but it is notable that overall, they form much the same proportion of the total in Fairview as for the UK as a whole. In Fairview's case, the Welfare Borderline group comprises those families living in upper floors of social housing.

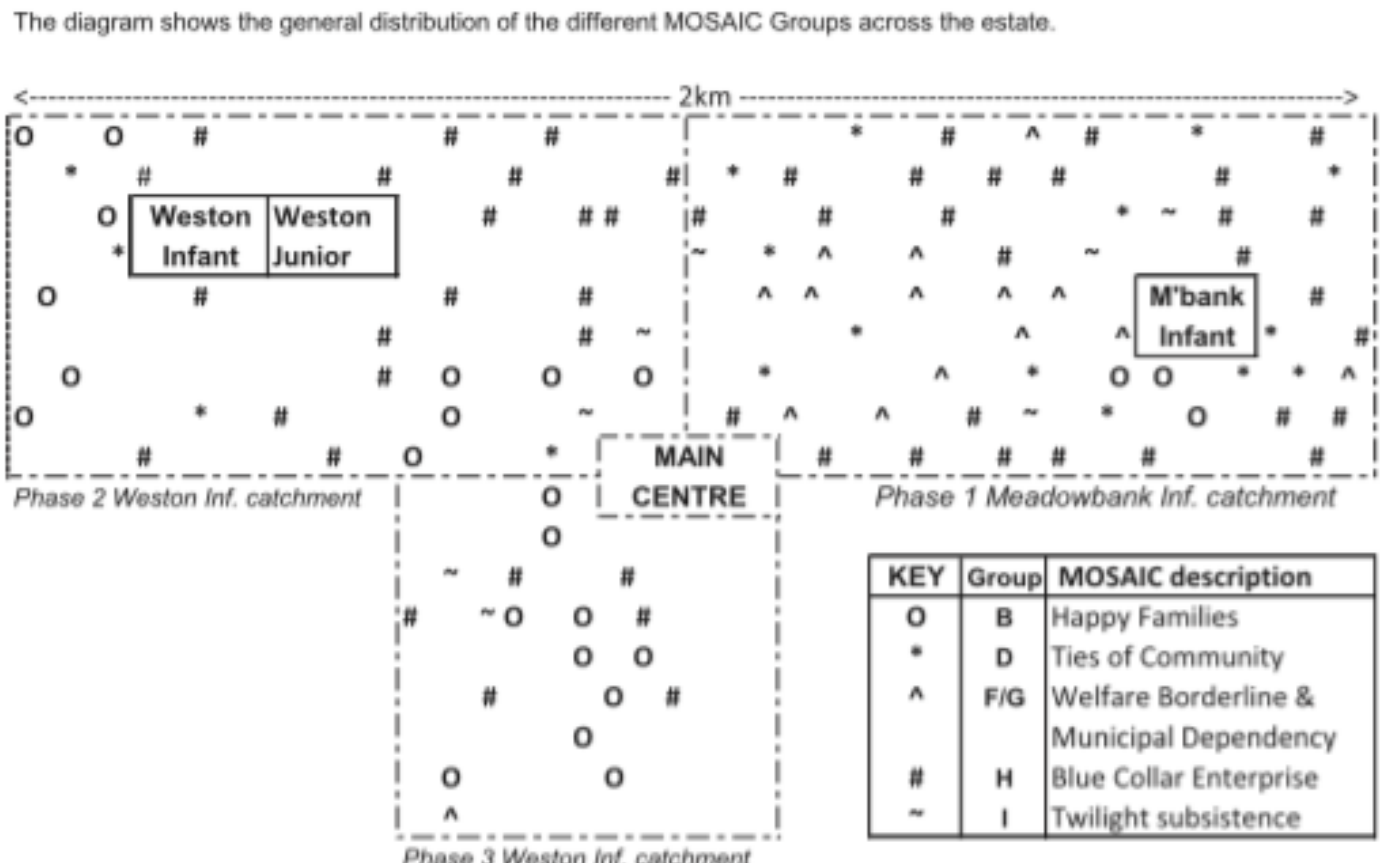

Table 1. Fairview - social variation by building phase.

The occupational structure of the estate is similar to other mixed-tenure estates which have been studied in detail and closely resembles that of North Township, one of two such estates discussed by Allen et al (2007), who described them as 'marginal' middle 
Camina, M. and Iannone, P. (2014). Housing mix, school mix: barriers to success. Journal of Education Policy. 29(1), 19-43.

class neighbourhoods. This term is used both to indicate that the middle-class households are at the lower end of the professional labour market and to suggest that the neighbourhood is 'spoilt' by the presence of social housing. Both areas have only $4.5 \%$ of households in higher managerial and professional occupations, well below the national average. Fairview has $26.4 \%$ and North Township $30.1 \%$ in lower managerial and professional occupations and intermediate occupations including small employers and own-account workers. Both have $9.6 \%$ of households in technical and supervisory work. The proportions in semi-routine and routine occupations are $32.4 \%$ and $32.2 \%$ respectively. (See Table 2.) Home owners here are primarily seeking value for money; they lack the economic capital to aim for suburban landscapes of privilege (Silverstone 1997) or the cultural capital to join the gentrifiers in the inner-urban neighbourhoods (Butler and Robson 2003). For Fairview, this point can be echoed in MOSAIC terms; the groups not represented, discounting those comprising elderly or rural households, are those named Symbols of Success, Suburban Comfort and Urban Intelligence.

\begin{tabular}{|lccccc|}
\hline Socio-Economic Classifications & \multicolumn{2}{c}{ Fairview } & \multicolumn{3}{c|}{ North Township } \\
based on Household Reference Person & Estate & City & Estate & City \\
1. Higher managerial \& professional occupations & 4.5 & 9.6 & 4.5 & 8.5 & 8.7 \\
2. Lower managerial \& professional occupations & 12.9 & 19.0 & 15.9 & 19.0 & 18.9 \\
3. Intermediate occupations & 9.2 & 7.5 & 10.5 & 6.1 & 9.5 \\
4. Small employers \& own account workers & 4.3 & 6.5 & 3.7 & 11.1 & 7.1 \\
5. Lower supervisory and technical occupations & 9.6 & 7.8 & 9.6 & 9.4 & 7.2 \\
6. Semi-routine occupations & 18.1 & 11.2 & 16.2 & 10.5 & 11.8 \\
7. Routine occupations & 14.1 & 12.0 & 16.2 & 10.5 & 9.1 \\
8. Never worked and long term unemployed & 4.2 & 3.2 & 4.6 & 1.8 & 3.6 \\
Not classified & 23.2 & 23.0 & 18.7 & 23.1 & 24.2 \\
Source 2001 Census of Population. Table 46. Crown Copyright. & & & & &
\end{tabular}

Table 2. Socio-economic classifications. 
Camina, M. and Iannone, P. (2014). Housing mix, school mix: barriers to success. Journal of Education Policy. 29(1), 19-43.

\section{Competing Neighbourhood Schools}

We now examine school destinations, looking at each stage of schooling in turn.

Necessarily, this starts with a brief summary of policy changes and then the scene is set by extracts from the interview data. The Local Authority data on school destinations is described in both geographical and historical terms.

There are two schools for the youngest children, Meadowbank Infants and Weston Infants. In the 1990s, the authority expected children to attend their nearest school and this was the norm. More formal systems for expressing preference were introduced from 2003 onwards, and, in 2007, there was a change in the pattern of schooling from First Schools, with a leaving age of eight, to Infant Schools with a leaving age of seven. The reports of the national inspectors (OFSTED) show a divergence in the schools' fortunes over time. At their first inspections (1994 and 1996) both schools were deemed to be 'good'. By the end of the period covered by our study, Weston Infants was deemed 'outstanding', with Meadowbank Infants being 'satisfactory'.

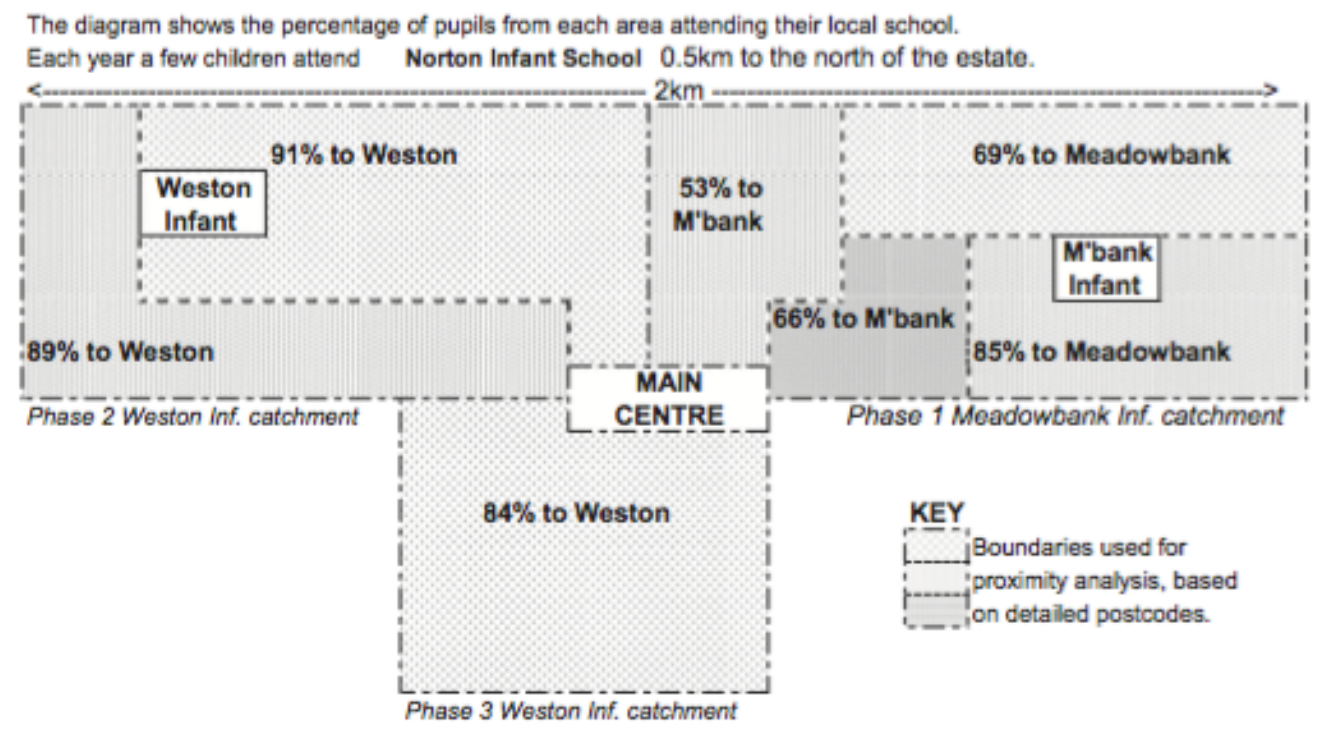

Figure 2. Fairview Infant Schools. Pupil destinations by post-zone. Source: LA database. Year 
Camina, M. and Iannone, P. (2014). Housing mix, school mix: barriers to success. Journal of Education Policy. 29(1), 19-43.

0 entries Sept 1997 to Sept 2007 for the two Fairview schools. (798 pupils).

The voice of this mother encapsulates the way in which parents balance personal convenience, local reputation and official information:

Hopefully she will go to [Weston Infants]. It's closer to me .... 'cos my niece goes there and I pick her up on a Friday, so it's handy if the little one goes there as well

but although she insists that:

I just prefer [Weston Infants] because it is the nearest, she also mentions that she herself used to attend the other school but that's gone downhill a hell of a lot 'cos one of my friends work there so I don't really want any of that so [Weston Infants] got good reviews and so that suits me getting her in there. (Mother).

While some parents relied on personal experience of the schools, albeit from twenty years ago, others looked on-line for information and for another mother, the decision (to reject both local schools) was based on observation:

the parents standing outside the schools and just the sight of them, I mean that may not be the school's fault, the school may not be too bad but....my children will be mixing with children that are from bad homes basically. (Mother).

Local Authority data for Year 0 entries is available for September 1997 to September 2007. Figure 2 shows that proximity is still a prime factor in the choice of school for the youngest children but it is much stronger for the Weston catchment where $86 \%$ of pupils went to their nearest school than for Meadowbrook (65\%). (Only a few pupils go off the estate at this age.) Movement across the estate is not all in the direction of 
Camina, M. and Iannone, P. (2014). Housing mix, school mix: barriers to success. Journal of Education Policy. 29(1), 19-43.

Weston Infants but this school has consistently attracted a higher proportion of estate pupils overall (Figure 3). This was most marked in September 1999, following the OFSTED report the previous February, putting Meadowbank Infants into special measures. More than ten years after this event, it is not possible to assess whether parents' prior concerns, a change of head teacher or the inspection itself and the associated media reporting discouraged parents from using their nearest school. The school was deemed 'satisfactory' in September 2002 but its problems were spelt out in some detail, which may have discouraged parents the following year. There appears to be only a small and short-lived link between OFSTED reports and parents' reactions.

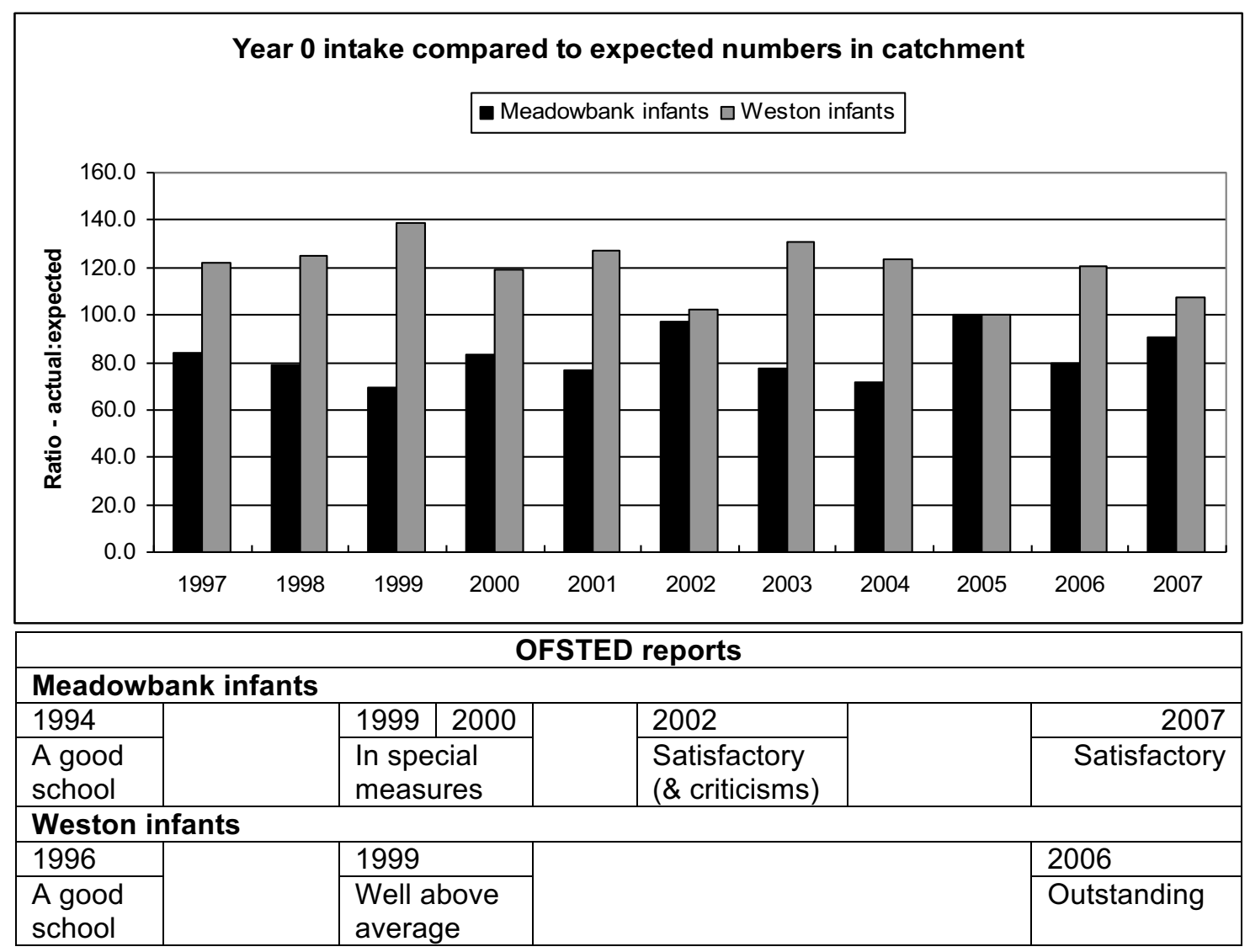

The 4-point overall assessment of Outstanding, Good, Satisfactory and Inadequate was not used in the earlier reports and the authors have provided their own summary.

Figure 3. Fairview Infant Schools. Pupil destinations by cohort. 
Camina, M. and Iannone, P. (2014). Housing mix, school mix: barriers to success. Journal of Education Policy. 29(1), 19-43.

\section{The Estate Junior School.}

For the rest of primary education, there is a single school on the estate. As explained, the pattern of schooling changed during the period and our interviews here were with Year 3 pupils:

In September, all the people who [are] in [my year] will probably be going to [Weston Juniors] (Year Three girl in 2004).

The children took this move for granted and so did the parents on the estate. Weston Juniors is a Voluntary Aided school i.e. state-funded with some initial capital funding input from the Church of England and a Christian ethos which parents must be willing to accept. Since formal preferences have been introduced, priority has been given to children living on the estate and, secondly, to those attending local schools. It is worth noting that a further proposal to change the pattern of primary schooling on the estate was considered in 2008 but ultimately rejected in favour retaining a single school serving the whole estate. As one local professional argued

I think people do need to mix and you don't need to isolate parts of the community .... It would be very easy to separate out because of the social mix of the housing. (Professional)

In the pupil focus groups, only two children were not following the estate 'norm'. One girl explained that she was going to Norton Junior (in the neighbouring suburb) 
Camina, M. and Iannone, P. (2014). Housing mix, school mix: barriers to success. Journal of Education Policy. 29(1), 19-43.

because it was "close on the way to Mum's work... and she can drop me off" but it seems likely that there were other considerations because she also knew she would be

"going to [Norton Secondary] because it's much easier 'cos you're first at [Norton Junior]". (Year 3 girl)

Attendance at Norton Junior does indeed give pupils greater priority for admission to Norton Secondary, as we shall see, and reminds us that, for some parents, the choice at this stage is influenced by their considerations of secondary education.

Local Authority data confirm the high level of support for the estate school, although some parents (16\% over the years) opted for Norton Junior (Figure 4). An estimated five pupils per year go elsewhere, some to attend a Roman Catholic School. On two occasions, the proportion of pupils going to Norton Junior has risen above $20 \%$. This occurred in September 1998, following the OFSTED report a year earlier which considered the estate school to be acceptable but highlighted serious weaknesses and again in September 2000, following the OFSTED report in the Spring which put the estate school into special measures. There was a swing the following year, when Norton Junior had also gone into special measures. Since then, fluctuations have been small (Figure 5) and both schools are currently thriving. The indications are that official reports have had a small impact but not one that has been long-lasting. 
Camina, M. and Iannone, P. (2014). Housing mix, school mix: barriers to success. Journal of Education Policy. 29(1), 19-43.

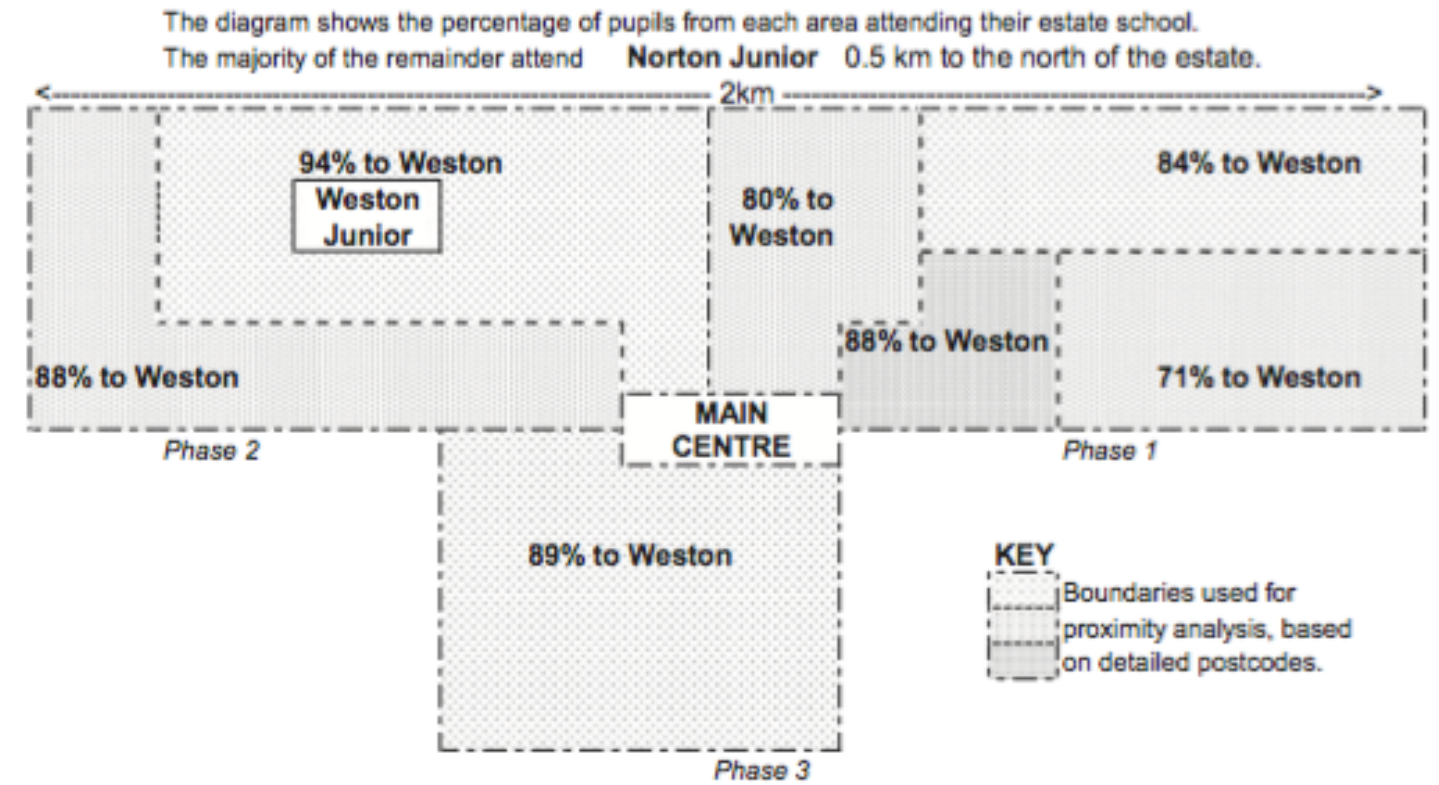

Figure 4. Junior Schools in and near Fairview. Pupil destinations by post-zone. Source: LA database. Year 3/4 entries Sept 1997 to Sept 2007 for the two nearest schools. (857 pupils).

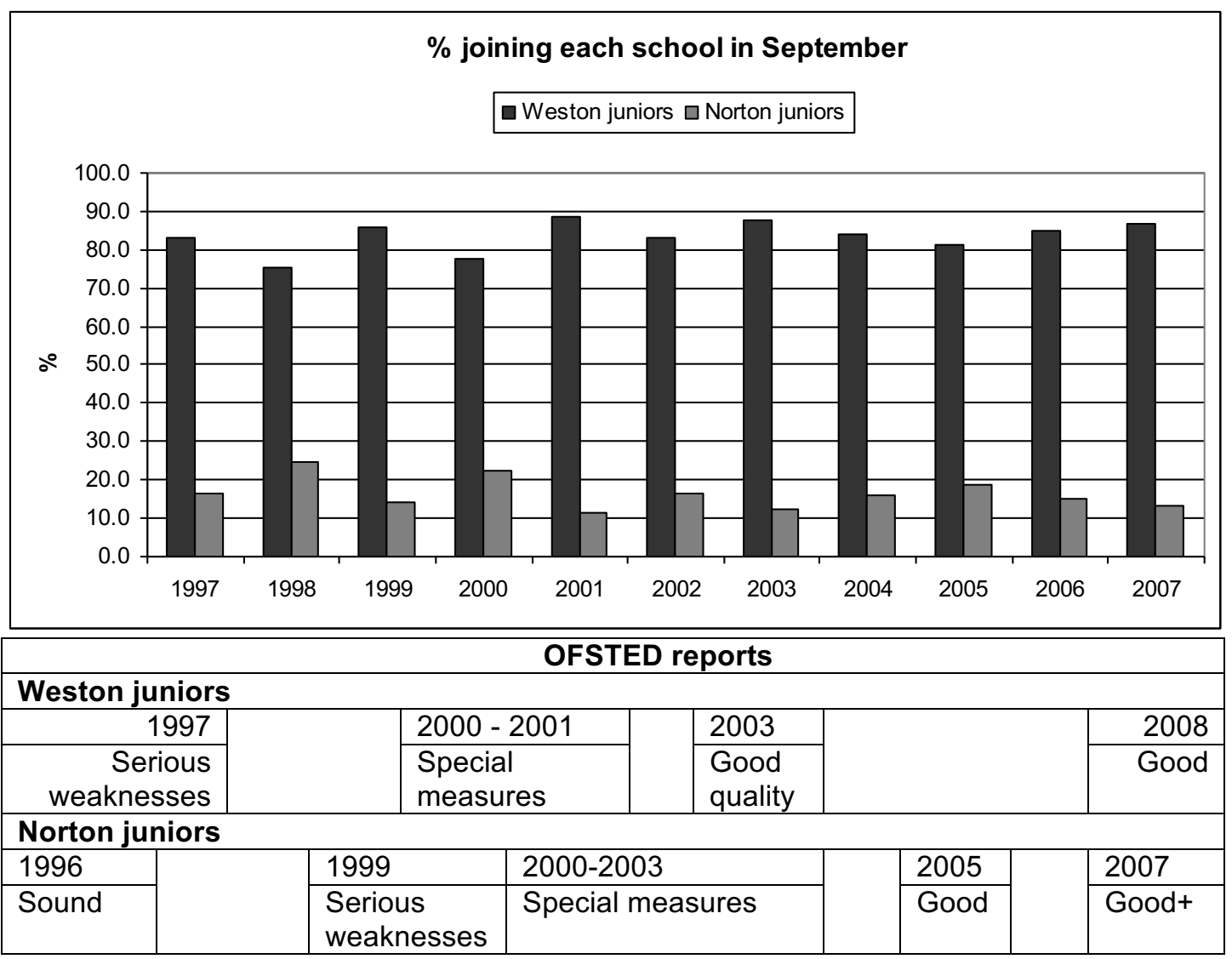

The 4-point overall assessment of Outstanding, Good, Satisfactory and Inadequate was not used in the earlier reports and the authors have provided their own summary.

Figure 5. Junior Schools in and near Fairview. Pupil destinations by cohort. 
Camina, M. and Iannone, P. (2014). Housing mix, school mix: barriers to success. Journal of Education Policy. 29(1), 19-43.

\section{Secondary Choice - the Admission Arrangements}

Policy changes, particularly over admissions, and changing reputations have had most impact at secondary level. Initially, Fairview residents, like any other residents in the pre-1974 Local Authority, had a choice from its six comprehensive schools. All were co-educational and could provide 'sixth form' education i.e. covering the two years after compulsory education. In the early 1970s, an authority-wide admission system known as banding had been introduced with children assessed in their last year at primary school and placed in five different ability bands. Parental choice was subject to each school receiving the same proportion of each of the ability groups; the rules were later softened so that the aim was to achieve a similar mix of children of different abilities, thus making it more likely that appeals would succeed. This system remained in place until the early 1990s following the 1988 Education Act.

While there have been some variations in the admission arrangements over the period of our study, Fairview pupils have consistently had priority at three schools deemed to serve the area (labelled here as Elmham, Treetops, Hawthorns). Treetops was consistently oversubscribed and allocations were then made on the basis of the straight line distance between home and school. Fairview is the most distant of the suburbs which it served and the likelihood of acceptance was low. The nearest school, Norton Secondary in the adjacent suburb of Norton, is in a different grouping and Fairview is not considered to be part of the area served by the school. After the preferences of pupils within its catchment are met, Fairview pupils who have attended Norton Junior are admitted before those who attended Weston Junior. During the period of the study, the local authority was the admissions authority except at Norton Secondary (which 
Camina, M. and Iannone, P. (2014). Housing mix, school mix: barriers to success. Journal of Education Policy. 29(1), 19-43.

used very similar criteria) and the Roman Catholic secondary school. The link between neighbourhood and school, therefore, depended crucially on the attitudes of parents and pupils to schools lying beyond their familiar environment and to the use of proximity criteria in cases where schools were oversubscribed.

\section{Secondary Destinations - the View from Year Six}

This is a neighbourhood where many of the parents and relatives had attended the schools being discussed and their experience (favourable or unfavourable) weighed strongly. Although all schools had open evenings to enable parents and pupils to participate in the choice process, many families seemed only to have visited the single school which they planned to opt for. For others, although they visited several schools and enjoyed the displays and demonstrations, the choice was a foregone conclusion:

[My mother] only put down [Elmham]. She didn't put down any other schools. Didn't chase round any choice. (Boy).

For most pupils, the comparison was between the two nearest schools, Elmham and Norton Secondary. Proximity is linked with familiarity and convenience. Overwhelmingly, children wanted to go where their friends and siblings did and this suited the parents. Faced with a move away from their familiar environment, nearby schools were also seen as offering security and this was very important to the pupils:

I’ve got my nanny live just up the road from [Elmham] so if I did ever get bullied or something, I've got someone close. (Boy)

It's nice knowing people who already go to the school [Norton Secondary], the people who live round our close. (Girl) 
Camina, M. and Iannone, P. (2014). Housing mix, school mix: barriers to success. Journal of Education Policy. 29(1), 19-43.

Most discussions centred on whether Elmham had been chosen or avoided but only one boy (and it is probably significant that he had recently moved from London, with some established views of secondary school) had been really worried about this school:

First of all I was going to [Elmham], that was my choice because I thought it might be the best school but then all my mates in my kind of year, they were going to [Norton Secondary] and I changed 'cos that seemed a nice school and 'cos I was [going to] one of the worst schools or something. [Interviewer: Do you know why?] Because people get bad grades and they get beaten up and they have security people around the school because that's how dangerous it is for kids. (Boy).

The pupils generally agreed that Elmham was not a very good school, although they only condemned it strongly if no-one in the focus group was going. Knowledge of the "terrible", "rubbish" results was widespread, not surprisingly, because there had been extensive press coverage, but few children realised that Norton Secondary had also been judged to be a failing school.

Given that the majority were going to schools without good results, the pupils were keen to say that this did not matter:

I don't think it [matters] because we could change it .... you should be proud of what you do. (Girl)

We could work hard. At least we tried. (Boy)

It was also necessary to be optimistic about 'special measures': 
Camina, M. and Iannone, P. (2014). Housing mix, school mix: barriers to success. Journal of Education Policy. 29(1), 19-43.

They're going to come off them this year I heard ... every single school I've been

to has been in special measures but apparently special measures like helps

the school, like gives it all money and they do better. (Girl)

In contrast, pupils going to Hawthorns were more aware of that school's examination results and more sure that they mattered:

I think it does [matter] for your future because if you have like bad results that will go on with the job you can get. (Girl)

If you get higher exam results it can tell you that most of the children there aren't that disruptive. (Boy)

One girl explained that her parents had over-ruled her choice of Norton Secondary in favour of a school with good results in a village $4.6 \mathrm{~km}$ away:

It's got smaller classes and it's really good. It was a bit annoying but my mum told me that my friends were going there. (Girl)

The plan was that this mother was going to provide transport for the other children as well. We know also that her father had been to university and it seems likely that it was when Norton Secondary went back into special measures just before choices had to be finalized that the parents decided to take charge of the process.

Treetops is also part of the southern group. The discussions about it were limited to reactions to the photograph, as only one of the pupils in the focus groups had visited the school. The main building dates from the turn of the century. The photograph was generally not recognised (a lack of familiarity even in a small City) and it attracted the immediate comment that 
Camina, M. and Iannone, P. (2014). Housing mix, school mix: barriers to success. Journal of Education Policy. 29(1), 19-43.

It looks a bit like Hogwarts. 'Cos they've got like a massive hall, rows of tables down the hall. (Boy)

It is nearly forty years since this school was the boys' grammar school but reputations die hard and the accepted wisdom was that

You have to be brainy to go in there. (Other Boy)

It was clear from other comments that the two local schools (with buildings dating mainly from the 1950s and 1960s) set a standard of architecture that equalled "school". A newer school was guessed to be part of the university and the former girls' grammar school was tentatively identified as a private school. This implies an expectation that only the 'ordinary' and 'familiar' is for them.

\section{Secondary Destinations - Local Authority Data}

Once Fairview children were able to attend Norton Secondary, it became the most popular choice and over the past twelve years, has attracted $52 \%$ of pupils, with clear geographical variation, favouring proximity (Figure 6). Some of these pupils will have attended Norton Junior specifically to help ensure this outcome. Elmham, Treetops and Hawthorns were the schools deemed to serve the area and Figure 7 shows the relative popularity of these options in comparison with Norton, together with the public data which forms the basis for local press reporting and guides some parents in their choice of school.

It can be seen that, judged by examination results, Treetops has been consistently the best performing school. It had an intake of 220 from September 2000 onwards (having been permitted to grow) and has remained consistently oversubscribed. In 2008, the most distant pupil accepted lived $2.4 \mathrm{~km}$ from the school and, as Figure 6 indicates, all 
Camina, M. and Iannone, P. (2014). Housing mix, school mix: barriers to success. Journal of Education Policy. 29(1), 19-43.

of Fairview lies beyond this cut-off. Hawthorns, which is the most distant school, fell rapidly out of favour when it was judged to have serious difficulties in March 2004 and went into special measures in the December. A professional commented that, within a year, the applications to this school from all over its catchment dropped dramatically. By 2008, it was just full and not oversubscribed; the most distant pupil accepted lived over $11 \mathrm{kms}$ away. For Norton Secondary, being a well-known and locally popular school one period in special measures had only a limited impact but going into special measures for a second time seems to have created a greater loss of confidence. For Elmham, the low standards of attainment and consequent position in League Tables, accompanied by high profile press reporting, seems to have been more important to parents than the nuanced OFSTED reports which (in 1994, 1997 and 2002) recognised the quality and commitment of teachers and the gradual improvement in results. However, there were subsequent internal difficulties, the improvements were not sustained and Fairview parents voted with their feet. Overall, a much wider range of alternatives is now being considered.

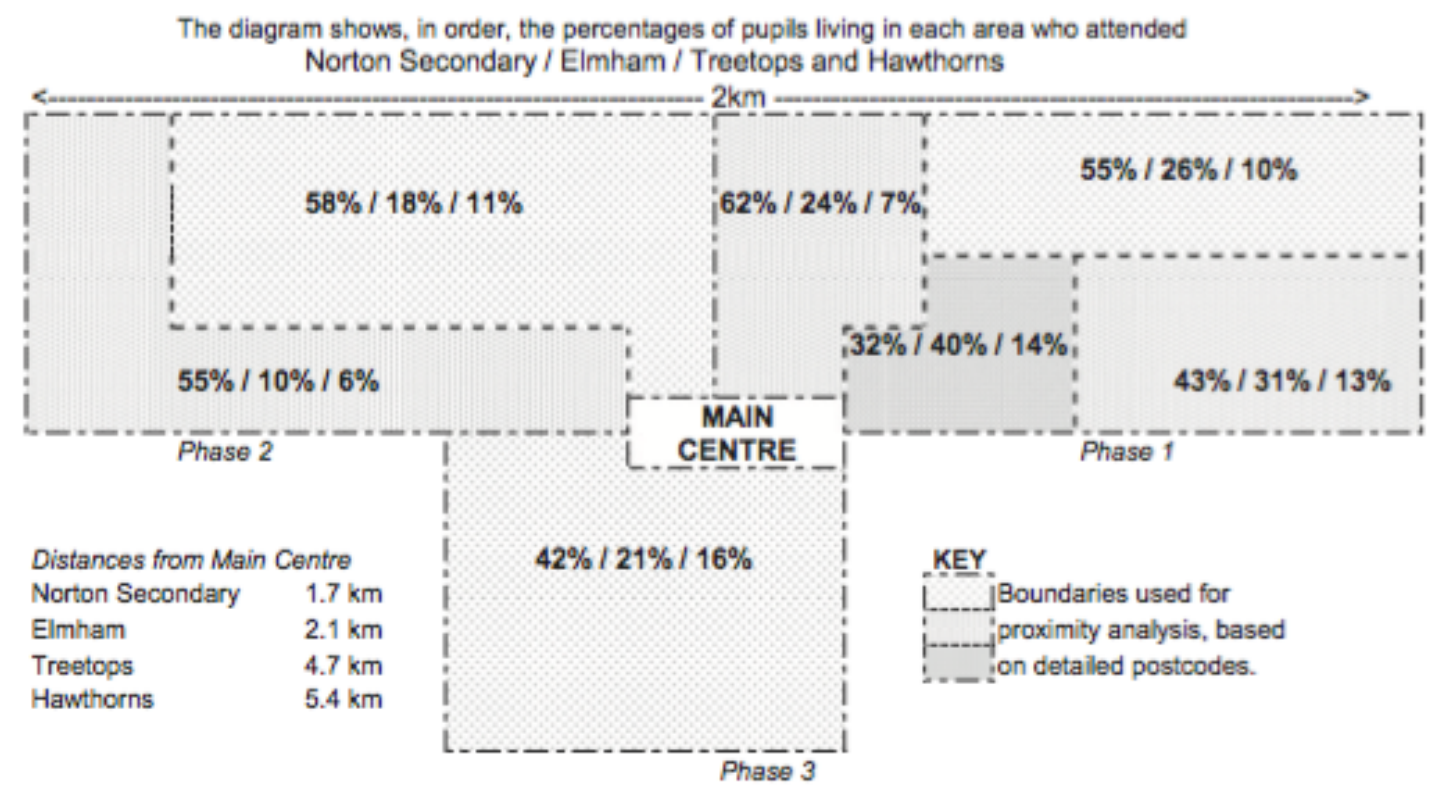

Figure 6 Secondary school pupils destination by post-zone. Source: LA database. Year 7/8 entries Sept 1997 to Sept 2007 for schools within $10 \mathrm{~km}$. (1103 pupils). 
Camina, M. and Iannone, P. (2014). Housing mix, school mix: barriers to success. Journal of Education Policy. 29(1), 19-43.

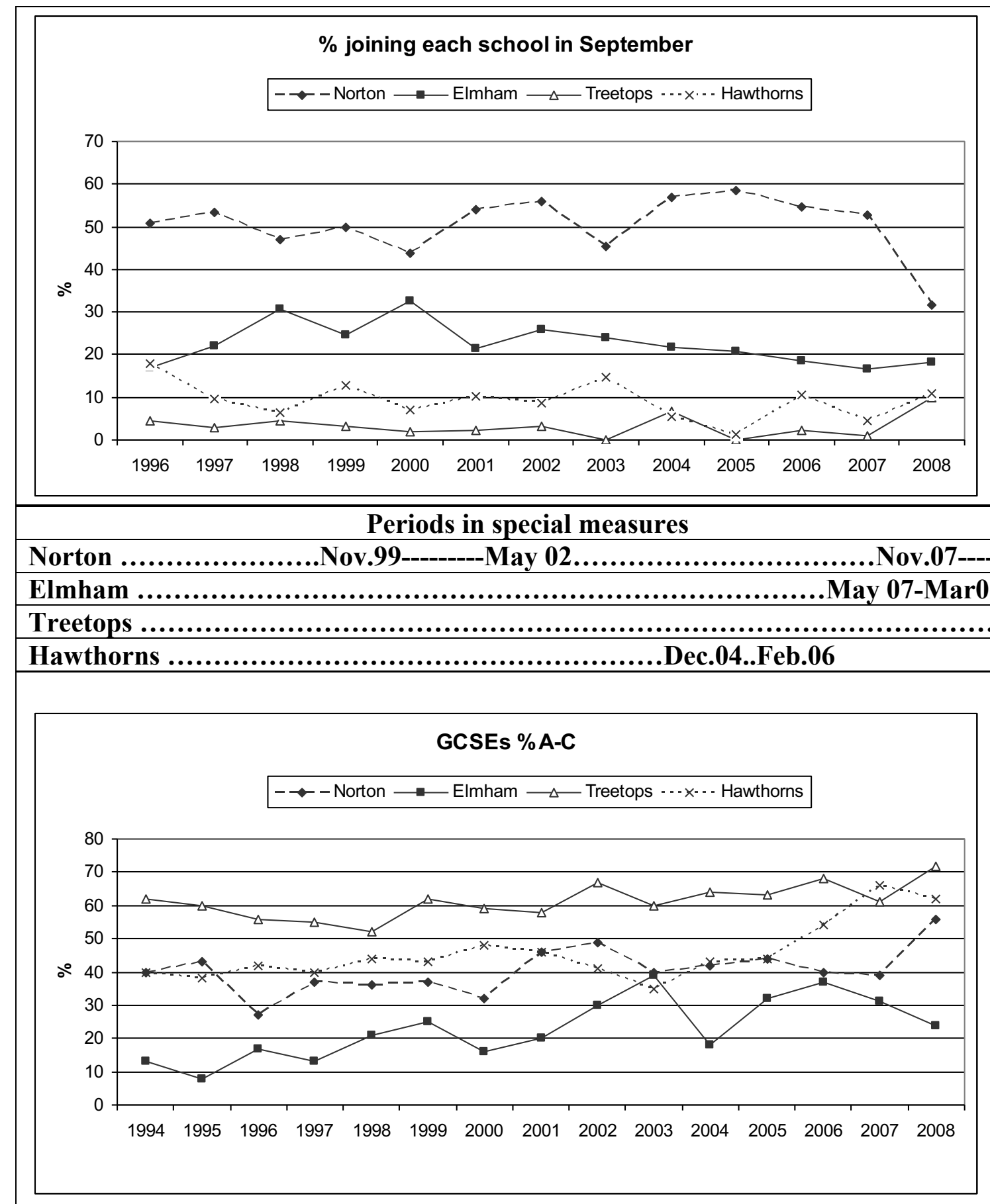

The graphs show the $\%$ of pupils obtaining $5 \mathrm{~A}-\mathrm{C}$ grades in the public examinations taken by all pupils in the year they reach age 16 . For the period covered, this also represented the end of compulsory education.

Figure 7. Secondary schools. Pupil destinations by cohort and one 'measure' of the schools. 
Camina, M. and Iannone, P. (2014). Housing mix, school mix: barriers to success. Journal of Education Policy. 29(1), 19-43.

\section{Discussion}

We have seen that this mixed-tenure suburban setting is neither privileged nor deprived. Although certain middle-class groups are absent, the analysis nevertheless reveals contrasting attitudes to schooling and school choice among the social groups represented. First, we use the pupil data to explore school destinations by tenure (Table 3) and MOSAIC Group (Table 4). Tenure differences are most distinctive at secondary level while Table 4 reveals that, at all stages, there are significant variations by Group. At infant level, while all Groups can and do consider a move outside their catchment, Ties of Community families in Meadowbank area are significantly more likely to choose an alternative school, so that the school whose catchment has fewest owner occupiers loses a significant proportion of them. Movement in the other direction is not strongly linked to social group. At junior school level, Happy Families appear most satisfied with their local choice and the mixture of social groups in the school, while Ties of Community have a greater tendency to go off the estate, in some cases continuing the choice they made at infant school. It is at the secondary stage that we see the clearest social differentiation in the choices being made. While all groups favour Norton Secondary, there is a stronger negative reaction to Elmham among the two more middle class groups. The other distinctive difference is that the poorest pupils are least likely to attend the most distant school. 
Camina, M. and Iannone, P. (2014). Housing mix, school mix: barriers to success. Journal of Education Policy. 29(1), 19-43.

\begin{tabular}{|l|r|r|r|r|r|r|r|r|}
\hline (a) $\begin{array}{l}\text { Fairview } \\
\text { Infants }\end{array}$ & \multicolumn{4}{|c|}{$\begin{array}{c}\text { Meadowbank Catchment } \\
\text { * }\end{array}$} & $\begin{array}{c}\text { Moving } \\
*\end{array}$ & Total & \multicolumn{4}{c|}{$\begin{array}{c}\text { Weston Catchment } \\
\text { Moving }\end{array}$} & $\begin{array}{l}\text { Local } \\
*\end{array}$ & $\begin{array}{c}\text { Moving } \\
*\end{array}$ & Total & $\begin{array}{c}\% \\
\text { Moving }\end{array}$ \\
\hline $\begin{array}{l}\text { Owner } \\
\text { occupiers }\end{array}$ & 52 & 35 & 87 & $\mathbf{4 0 . 2}$ & 235 & 39 & 274 & $\mathbf{1 4 . 2}$ \\
\hline $\begin{array}{l}\text { LA cul- } \\
\text { de-sacs }\end{array}$ & 173 & 87 & 260 & $\mathbf{3 3 . 5}$ & 31 & 10 & 41 & $\mathbf{2 4 . 4}$ \\
\hline $\begin{array}{l}\text { HA } \\
\text { tenants }\end{array}$ & 24 & 10 & 34 & $\mathbf{2 9 . 4}$ & 75 & 7 & 82 & $\mathbf{8 . 5}$ \\
\hline Total & 249 & 132 & 381 & $\mathbf{3 5 . 9}$ & 347 & 57 & 404 & $\mathbf{1 4 . 1}$ \\
\hline
\end{tabular}

${ }^{*}$ Local $=$ those attending the school in their catchment. Moving $=$ those going out of catchment to the other Fairview infant school or (estimated) to Norton Infant school.

\begin{tabular}{|c|c|c|c|c|}
\hline \multirow{2}{*}{$\begin{array}{l}\text { (b) } \\
\text { Fairview } \\
\text { Juniors }\end{array}$} & \multicolumn{4}{|c|}{ Weston Catchment } \\
\hline & $\underset{*}{\text { Local }}$ & $\underset{*}{\text { Moving }}$ & Total & $\begin{array}{c}\% \\
\text { Moving }\end{array}$ \\
\hline $\begin{array}{l}\text { Owner } \\
\text { occupiers }\end{array}$ & 292 & 61 & 353 & 17.3 \\
\hline $\begin{array}{l}\text { LA cul-de- } \\
\text { sacs }\end{array}$ & 273 & 46 & 319 & 14.4 \\
\hline $\begin{array}{l}\mathrm{HA} \\
\text { tenants }\end{array}$ & 107 & 9 & 116 & 7.8 \\
\hline Total & 672 & 116 & 788 & 14.7 \\
\hline
\end{tabular}

* Local $=$ those going to Weston Junior. Moving $=$ those going to Norton Junior.

Variation by tenure is significant at the $5 \%$ level as measured by chi-square

\begin{tabular}{|c|c|c|c|c|c|c|c|c|c|c|}
\hline \multirow{2}{*}{$\begin{array}{l}\text { (c) } \\
\text { Secondary } \\
\text { Schools }\end{array}$} & \multicolumn{2}{|c|}{ Norton } & \multicolumn{2}{|c|}{ Elmham } & \multicolumn{2}{|c|}{ Treetops } & \multicolumn{2}{|c|}{ Hawthorns } & \multicolumn{2}{|c|}{ Total } \\
\hline & No. & $\%$ & No. & $\%$ & No. & $\%$ & No. & $\%$ & No. & $\%$ \\
\hline $\begin{array}{l}\text { Owner } \\
\text { occupiers }\end{array}$ & 214 & 62.9 & 70 & 20.6 & 10 & 2.9 & 46 & 13.5 & 340 & 100.0 \\
\hline $\begin{array}{l}\text { LA cul-de- } \\
\text { sacs }\end{array}$ & 244 & 57.5 & 130 & 30.7 & 16 & 3.8 & 34 & 8.0 & 424 & 100.0 \\
\hline $\begin{array}{l}\mathrm{HA} \\
\text { tenants }\end{array}$ & 64 & 56.1 & 38 & 33.3 & 1 & 0.9 & 11 & 9.6 & 114 & 100.0 \\
\hline Total & 522 & 59.5 & 238 & 27.1 & 27 & 3.1 & 91 & 10.4 & 878 & 100.0 \\
\hline
\end{tabular}

Variation by tenure is significant at the $1 \%$ level as measured by chi-square

Source for all Tables: the LA pupil data base and data from the District Council on tenure

Table 3. School destinations - analysed by tenure.

Previous research has shown that "choice is a marker of economic privilege" (Reay and Lucy 2003, 138). Typically, the middle classes are more informed and more financially able to contemplate sending their child to a school other than the local 
Camina, M. and Iannone, P. (2014). Housing mix, school mix: barriers to success. Journal of Education Policy. 29(1), 19-43.

school, while for the working-class families studied by Vincent et al (2010), factors of convenience, familiarity and proximity are key elements in the choice process. However, the example of our infant schools brings out a different feature. Where people are not constrained by a lack of understanding of the system, the potential schools are familiar and there are limited barriers in terms of cost and time, we find families of all tenures and all social groups choosing a marginally less convenient school which seems to offer a better education. It must be acknowledged, however, that such conditions are rare.

Fairview children come together at the next stage, where Weston Junior reflects the estate as a whole and has a mixed intake. This is not "every child", as in the early days when school choice was not part of the language or expectations of parents. However, the school does not suffer from a significant outflow of any one group of parents and the different aspirations of pupils recorded in the focus groups confirm that it continues to reflect the estate as a whole.

All children must leave Fairview for secondary education and it is here that we see the greatest divergence by class, although largely within the narrow context of choosing between two non-selective state schools. It is at this transition point that the young people's apprehension about potential bullying and concerns about how to deal with it were clearly expressed. In general, this serves to confirm the advantage of a local school, as there will be siblings, friends and nearby adults to turn to. The challenge (and cost) of a long journey to school is also avoided. The recent study by SQW Consulting (2010) shows that nearly two-thirds of parents put location and ease of access as their key criteria when choosing a school. Of course, ease of access can 
Camina, M. and Iannone, P. (2014). Housing mix, school mix: barriers to success. Journal of Education Policy. 29(1), 19-43.

\begin{tabular}{|c|c|c|c|c|c|c|c|c|}
\hline \multirow{2}{*}{$\begin{array}{l}\text { (a) } \\
\text { Fairview } \\
\text { Infants }\end{array}$} & \multicolumn{4}{|c|}{ Meadowbank Catchment* } & \multicolumn{4}{|c|}{ Weston Catchment } \\
\hline & $\begin{array}{c}\text { Local } \\
*\end{array}$ & $\underset{*}{\text { Moving }}$ & Total & $\begin{array}{c}\% \\
\text { Moving }\end{array}$ & $\begin{array}{c}\text { Local } \\
*\end{array}$ & $\underset{*}{\text { Moving }}$ & Total & $\begin{array}{c}\% \\
\text { Moving }\end{array}$ \\
\hline $\begin{array}{l}\text { Happy } \\
\text { Families }\end{array}$ & - & - & $<5$ & - & 162 & 32 & 194 & 16.5 \\
\hline $\begin{array}{l}\text { Ties of } \\
\text { Community }\end{array}$ & 36 & 37 & 73 & 50.7 & 20 & 1 & 21 & 4.8 \\
\hline $\begin{array}{l}\text { Blue Collar } \\
\text { Enterprise }\end{array}$ & 172 & 91 & 263 & 34.6 & 138 & 22 & 160 & 13.8 \\
\hline $\begin{array}{l}\text { Welfare/ } \\
\text { Municipal }\end{array}$ & 69 & 28 & 97 & 28.9 & 18 & 1 & 19 & 5.3 \\
\hline Total & 277 & 156 & 433 & 36.0 & 338 & 56 & 394 & 14.2 \\
\hline
\end{tabular}

* Local $=$ those attending the school in their catchment. Moving $=$ those going out of catchment to the other Fairview infant school or (estimated) to Norton Infant school.

Variation by MOSAIC Group is significant at the $1 \%$ level as measured by chi-square

\begin{tabular}{|l|r|r|r|r|}
\hline (b) & \multicolumn{4}{|c|}{ Weston Catchment } \\
\cline { 2 - 5 } $\begin{array}{l}\text { Juniors } \\
\text { Juliow }\end{array}$ & $\begin{array}{c}\text { Moving } \\
\text { * }\end{array}$ & Total & $\begin{array}{c}\text { \% } \\
\text { Moving }\end{array}$ \\
\hline $\begin{array}{l}\text { Happy } \\
\text { Families }\end{array}$ & 165 & 17 & 182 & $\mathbf{9 . 3}$ \\
\hline $\begin{array}{l}\text { Ties of } \\
\text { Community }\end{array}$ & 87 & 27 & 114 & $\mathbf{2 3 . 7}$ \\
\hline $\begin{array}{l}\text { Blue Collar } \\
\text { Enterprise }\end{array}$ & 364 & 71 & 435 & $\mathbf{6 . 3}$ \\
\hline $\begin{array}{l}\text { Welfare/ } \\
\text { Municipal Dep }\end{array}$ & 98 & 18 & 116 & $\mathbf{1 5 . 5}$ \\
\hline Total & 714 & 133 & 847 & $\mathbf{1 5 . 7}$ \\
\hline
\end{tabular}

* Local $=$ those going to Weston Junior. Moving $=$ those going to Norton Junior.

Variation by MOSAIC Group is significant at the $1 \%$ level as measured by chi-square

\begin{tabular}{|c|c|c|c|c|c|c|c|c|c|c|}
\hline \multirow{2}{*}{$\begin{array}{l}\text { (c) } \\
\text { Secondary } \\
\text { Schools }\end{array}$} & \multicolumn{2}{|c|}{ Norton } & \multicolumn{2}{|c|}{ Elmham } & \multicolumn{2}{|c|}{ Treetops } & \multicolumn{2}{|c|}{ Hawthorns } & \multicolumn{2}{|c|}{ Total } \\
\hline & No. & $\%$ & No. & $\%$ & No. & $\%$ & No. & $\%$ & No. & $\%$ \\
\hline $\begin{array}{l}\text { Happy } \\
\text { Families }\end{array}$ & 87 & 65.9 & 23 & 17.4 & 4 & 3.0 & 18 & 13.6 & 132 & 100.0 \\
\hline $\begin{array}{l}\text { Ties of } \\
\text { Community }\end{array}$ & 94 & 69.1 & 21 & 15.4 & 4 & 2.9 & 17 & 12.5 & 136 & 100.0 \\
\hline $\begin{array}{l}\text { Blue Collar } \\
\text { Enterprise }\end{array}$ & 312 & 57.1 & 161 & 29.5 & 17 & 3.1 & 56 & 10.3 & 546 & 100.0 \\
\hline $\begin{array}{l}\text { Welfare/ } \\
\text { Municipal Dep }\end{array}$ & 70 & 53.0 & 48 & 36.4 & 5 & 3.8 & 9 & 6.8 & 132 & 100.0 \\
\hline Total & 563 & 59.5 & 253 & 26.7 & 30 & 3.2 & 100 & 10.6 & 946 & 100.0 \\
\hline
\end{tabular}

Variation by MOSAIC Group is significant at the $1 \%$ level as measured by chi-square Source for all Tables: the LA pupil data base and MOSAIC data supplied by Experian.

Table 4. School destinations - analysed by MOSAIC Group.

include a more distant school, if, for example, the location fits a parent's journey to work but, of interest here, is the low proportion of all groups opting for Treetops and 
Camina, M. and Iannone, P. (2014). Housing mix, school mix: barriers to success. Journal of Education Policy. 29(1), 19-43.

Hawthorns, the more distant schools which are also officially defined as 'serving the area'. Against such a choice are considerations of cost, of the pressure to conform to the estate norm and of the risk of rejection if a school with a more academic reputation is sought.

Our evidence on the process of school choice and the factors being considered by parents and children confirms previous work and that of itself is interesting, given that some of the key studies were carried out in the mid-1990s, frequently within an inner city context. Our case study is suburban and has few pupils from ethnic minorities but, nevertheless, pupils talk of a school to be avoided and the feeling that only the ordinary is for them; they develop a narrative for dealing with one's school having a poor reputation (Reay and Lucy 2003). Although at secondary level, we looked mainly at the pupils' view, it was clear that normally this was a family decision and that parents and children had a generalized awareness of a school's academic performance rather than a detailed understanding of results and league tables (West and Pennell 2000; Woods, Bagley and Glatter 1998). Similarly, there were references to both the press and school web sites couched in terms of the general impression obtained and only a few families focused on examination results.

There was a strong reliance on local 'grapevine' knowledge, particularly given that many parents had themselves attended local schools or knew people who worked there (Ball and Vincent 1998; Vincent et al 2010). Close friends and relatives were the people whose opinions were drawn on and trusted and we know from previous work that cross-tenure contact (except were family members were involved) tended to be formal, avoiding any exchange of personal information. (Allen et al. 2005). Overall, attitudes in Fairview compare well with Cheadle, described variously by Savage, 
Camina, M. and Iannone, P. (2014). Housing mix, school mix: barriers to success. Journal of Education Policy. 29(1), 19-43.

Bagnall and Longhurst (2005) as lower middle class, predominantly owner occupied and with a strong ethic of manual labour. They found that:

"[Many] of our respondents did not have the economic or cultural capital to make choices over schooling, and in general did not articulate schooling as a problem....In Cheadle [there was] a more passive acceptance that the local schools were 'OK' or even good." (Savage et al. 2005, 70).

Educational research using MOSAIC data is not yet extensive. Webber and Butler (2007) have demonstrated the importance of the neighbourhood where pupils live in predicting performance in public examinations at age sixteen. They also identified two of the 61 MOSAIC Types who do much less well at GCSE examinations than one might expect from their position in an overall ranking based on multiple deprivation. These are Type G42 Low Horizons (within Municipal Dependency), covering $2.6 \%$ of Fairview pupils and, more significantly for our case study, Type H47 New Town Materialism (within Blue Collar Enterprise), covering 36.9\% of Fairview pupils. They attribute the low educational attainment of this key group to traditional expectations of acquiring well-paid jobs, without the need for formal qualifications. Perhaps the dominance of this group here should not surprise us, since, although the estate offers value-for-money houses and a pleasant neighbourhood, any family really concerned to obtain a place for their child at a state secondary school with good examination results could not be certain of this outcome if they lived in Fairview because of its location in respect to such schools. The 2001 census shows that the proportion of adults with degree-level and equivalent qualifications or above is $10 \%$ for Fairview compared to $21 \%$ for the Local Authority as a whole. Even more significantly, the residential area 
Camina, M. and Iannone, P. (2014). Housing mix, school mix: barriers to success. Journal of Education Policy. 29(1), 19-43.

within a mile of Treetops (the school which has the most consistently good examination results) has $37 \%$ of adults with these qualifications. As Hamnett and Butler (2011) have shown for East London, 'geography matters' and when distance is a key criterion in the allocation of school places, educational inequalities are sustained and intensified. This finding is confirmed in the very different setting of a small City.

\section{Conclusions}

Attitudes to schools and school choice among Fairview parents and pupils reflect those identified in previous studies. The local and familiar offers huge practical and emotional advantages and only a few parents and children look beyond the immediate non-selective state schools. The focus on the local contrasts strongly with the official emphasis on diversity and choice (Department for Education, 2010) and SQW Consulting $(2010,99)$ reported that their findings that convenience dominated parents' choice of school posed "challenges for the choice agenda". Recent academic papers have been more overtly critical seeing the emphasis on choice as having 'toxic side effects (with) alienated parents who feel that they have been landed with a suboptimal outcome'. Butler and Hammnett 2010, 2448), while Vincent et al (2010, 295) point out that 'the benefits of and logic to prioritizing the local and known are not recognized within policy' and refer to the resultant 'increasingly pervasive inequality'.

In this mixed suburb, the single Junior school serving the whole estate did indeed reflect the estate as a whole but the question remains as to whether social mix in housing and social mix in education can usefully proceed jointly. In the UK, these concepts have tended to develop separately, although interestingly in France 'la mixité sociale' and 'la mixité scholaire' seem to be seen as parallel goals (Lupton and 
Camina, M. and Iannone, P. (2014). Housing mix, school mix: barriers to success. Journal of Education Policy. 29(1), 19-43.

Tunstall 2008, 115). New planned neighbourhoods, with a mix of tenures, do indeed reduce concentrations of poverty and are welcomed in both spheres. However, as Allen et al. (2005) found, in studying three such areas, they have tended to attract a relatively limited social range, in spite of offering a mix of tenure and a wide range of dwelling price and type. Our study indicates that this kind of newly planned neighbourhood may not create the sort of social mix which educationalists have in mind. What Head Teachers wanted for their school was a greater representation of professional occupations, increasing the proportion of parents they would expect to take a more active interest in education and in the school.

It may be possible to attract managerial and professional groups to such developments but this will depend on the planned neighbourhood's position in the local housing market, the general disposition of quality secondary schools and also the extent to which living in planned new areas chimes with people's self-image. Some level of social mix in schools can be planned successfully, particularly when a single school serves the neighbourhood as a whole, and attains a good reputation but the more affluent are always in a better position to overcome barriers of cost and time involved in seeking a better school beyond their estate, particularly at secondary level. They are also likely to develop their own group pressure in support of such a decision. The creation of balanced intakes remains a worthwhile goal for long-term planning. The answer on whether the long-term solution to socially segregated schools lies in urban planning and the reduction of residential segregation (Benn 1997) seems to be that it remains a worth-while goal but that the results are likely to be limited.

On a short-term basis therefore, one must acknowledge, with Brighouse (1997), that the practical and theoretical difficulties of creating balanced intakes are too great to 
Camina, M. and Iannone, P. (2014). Housing mix, school mix: barriers to success. Journal of Education Policy. 29(1), 19-43.

make this a key policy aim, especially when ideally one would wish to consider ethnicity and attainment as well as class. He prefers to emphasise the definition of a comprehensive school as "the common experience of all who happen to live in a particular place" (173).

The use of MOSAIC data has allowed us to explore pupil characteristics in more detail than usual and to take the analysis further than one provided by a simple classification of eligibility/non-eligibility for free school meals. As in Webber and Butler's paper (2007), we are able to come to a more nuanced understanding of different social groups and how this might impact on attitudes to education and the way in which schools need to work. Our findings support Thrupp and Lupton (2006) who argue the case for a much greater understanding of the context within which a school is operating, so that each school can receive the level and type of support needed. This is important whether or not one can achieve a balanced intake. 
Camina, M. and Iannone, P. (2014). Housing mix, school mix: barriers to success. Journal of Education Policy. 29(1), 19-43.

\section{Appendix 1. The MOSAIC Classification for Fairview.}

The MOSAIC post-code based classification system allocates households to one of 61 behavioural types and 11 groups, based on 400 data variables drawn from the 2001 Census, other public sources and from Experian's own sources including lifestyle surveys, consumer credit activity and house price information. Validity is checked by fieldwork and observational analysis.

\begin{tabular}{|c|c|c|c|}
\hline $\begin{array}{l}\text { Group \& } \\
\text { MOSAIC } \\
\text { description }\end{array}$ & $\begin{array}{c}\% \text { of } \\
\text { UK } \\
\text { households }\end{array}$ & $\begin{array}{l}\% \text { of } \\
\text { Fairview } \\
\text { pupils }\end{array}$ & $\begin{array}{l}\text { General Description of the Group } \\
\text { and the Types represented in Fairview. }\end{array}$ \\
\hline $\begin{array}{l}\text { B } \\
\text { Happy } \\
\text { Families }\end{array}$ & 10.8 & 21.7 & $\begin{array}{l}\text { Younger people living in newer homes. Two- } \\
\text { thirds of these households are Type B13, first } \\
\text { generation owner occupiers with large } \\
\text { amounts of consumer debt. Type B8 } \\
\text { (families living in developments built since } \\
\text { 2001) and B12 (middle-income families in } \\
\text { estates of modern private homes) are also } \\
\text { represented. }\end{array}$ \\
\hline $\begin{array}{c}\text { D } \\
\text { Ties of }\end{array}$ & 16.0 & 12.1 & $\begin{array}{l}\text { Close-knit, inner city and manufacturing } \\
\text { town communities. }\end{array}$ \\
\hline Community & & & $\begin{array}{l}70 \% \text { of these households are Type D } 23 \text {, } \\
\text { owners of affordable terraces, generally, but } \\
\text { not here, nineteenth century. The rest are } \\
\text { Type D } 22 \text {, comfortably off manual workers } \\
\text { living in spacious but inexpensive private } \\
\text { homes. }\end{array}$ \\
\hline $\begin{array}{l}\text { F } \\
\text { Welfare } \\
\text { Borderline }\end{array}$ & 6.4 & 7.7 & $\begin{array}{l}\text { People living in social housing with } \\
\text { uncertain employment in deprived areas. All } \\
\text { these households are Type F } 37 \text {, young } \\
\text { families living in upper floors of social } \\
\text { housing. They are grouped with } \mathbf{G} \text { for } \\
\text { analysis. }\end{array}$ \\
\hline $\begin{array}{l}\mathbf{G} \\
\text { Municipal }\end{array}$ & 6.7 & 5.8 & $\begin{array}{l}\text { Low-income families living in estate-based } \\
\text { social housing. }\end{array}$ \\
\hline Dependency & & & $\begin{array}{l}\text { Evenly split between Type G41, families, } \\
\text { many single parent, in deprived social } \\
\text { housing and Type G42, older people living } \\
\text { on very large social housing estates. }\end{array}$ \\
\hline $\begin{array}{l}\mathbf{H} \\
\text { Blue Collar }\end{array}$ & 11.0 & 51.0 & $\begin{array}{l}\text { Upwardly mobile families living in homes } \\
\text { bought from social landlords. }\end{array}$ \\
\hline Enterprise & & & $\begin{array}{l}70 \% \text { of these households are Type H47, } \\
\text { social housing, typically in 'new towns', } \\
\text { with good job opportunities for the poorly } \\
\text { qualified. The remainder are Type H46, } \\
\text { residents in council estates, now mostly } \\
\text { owner-occupiers, sometimes described as } \\
\text { 'white van culture'. }\end{array}$ \\
\hline
\end{tabular}


Camina, M. and Iannone, P. (2014). Housing mix, school mix: barriers to success. Journal of Education Policy. 29(1), 19-43.

The remaining six groups are: A. Symbols of success, C. Suburban comfort, E. Urban Intelligence, I. Twilight Subsistence, J. Grey Perspectives, K. Rural Isolation. 1.7\% of pupil addresses were either not classified or from these groups.

Sources: LA pupil post-code data (1871 pupils), the MOSAIC classification for Fairview and Experian documentation on MOSAIC Public Sector and MOSAIC UK. See www.business-strategies.co.uk for further detail on this proprietary geodemographic product. 
Camina, M. and Iannone, P. (2014). Housing mix, school mix: barriers to success. Journal of Education Policy. 29(1), 19-43.

\section{References}

Allen, C., M. Camina, R. Casey, S. Coward, and M. Wood. 2005. Mixed Tenure, twenty years on - Nothing out of the ordinary. York: Joseph Rowntree Foundation.

Allen, C., R. Powell, R. Casey, and S. Coward. 2007. 'Ordinary, the same as anywhere else': notes on the Management of spoiled Identity in 'Marginal' Middle-class Neighbourhoods. Sociology 47: 239-258.

Allen, R., J. Coldron, and A. West. 2012. The effect of changes in published secondary school admissions on pupil composition. Journal of Education Policy 27: 349-366.

Araujo, M. 2007. 'Modernising the comprehensive principle': selection, setting and the institutionalisation of educational failure. British Journal of Sociology of Education 28: 241-257.

Ball, S. J., and C. Vincent. 1998. "I heard it on the grapevine": Hot knowledge and School “Choice”. British Journal of Sociology of Education 19: 377-400.

Benn, C. 1997. Effective comprehensive education. In R. Pring, and G. Walford, eds. Affirming the comprehensive ideal. London and Washington DC: Falmer.

Benn, C., and C. Chitty. 1996. Thirty years on. London: David Fulton.

Bourdieu, P. 1984. Distinction. London: Routledge. 
Camina, M. and Iannone, P. (2014). Housing mix, school mix: barriers to success. Journal of Education Policy. 29(1), 19-43.

Brighouse, T. 1997. A local democratic framework. In R. Pring, and G. Walford, eds. Affirming the Comprehensive Ideal. London: Falmer Press.

Buck, N. 2001. Identifying neighbourhood effects on social exclusion. Urban Studies 38: $2251-2275$.

Butler, T., and C. Hamnett. 2007. The Geography of Education: Introduction. Urban Studies 44: 1161-1174.

Butler, T., and C Hamnett. 2010. 'You take what you are given': the limits to parental choice Environment and Planning A 42: 2431-2450.

Butler, T., and G. Robson. 2003. Plotting the middle classes: gentrification and circuits of education in London. Housing Studies 18: 5-28.

Camina, M., and M. J. Wood. 2009. Parallel lives: towards a greater understanding of what mixed communities can offer. Urban Studies 46: 459-480.

Cheshire, P., and S. Sheppard. 2004. Capitalising the value of free schools: the impact of the supply characteristics and uncertainty. The Economic Journal 114 499: 397-424.

Coldron, J., C. Cripps, and L. Shipton. 2010. Why are English secondary schools socially segregated? Journal of Education Policy 25: 19-35. 
Camina, M. and Iannone, P. (2014). Housing mix, school mix: barriers to success. Journal of Education Policy. 29(1), 19-43.

Communities and Local Government. 2010. Planning Policy Statement 3: Housing. $3^{\text {rd }}$

Edition. London: TSO. Retrieved from

http://www.communities.gov.uk/publications/planningandbuilding/pps3housing

Croft, J. 2004. Positive choice, no choice or total rejection: the perennial problem of school catchments, housing and neighbourhoods. Housing Studies 19:

927-945.

Davies, P., S. Telhaj, D. Hutton, N. Adnett, and R. Coe. 2008. Socioeconomic background, gender and subject choice in secondary schooling. Educational Research 50: $235-248$.

Department for Education. 2010 . The Importance of Teaching. Cm7980. London: TSO. Retrieved from

http://www.education.gov.uk/schools/teachingandlearning/schoolswhitepaper

Devine, F., M. Savage, J. Scott, and R. Crompton, eds. 2005. Rethinking class. Culture, Identities, Lifestyles. New York: Palgrave Macmillan.

Fairview Council. 1974. Fairview Master Plan. Fairview: Fairview Council.

Gewirtz, S., S.J. Ball, and R. Bow. 1995. Markets, Choice and Equity. Buckingham: OUP.

Goetz, E. 2002. Forced relocation vs. voluntary mobility: the effects of dispersal programmes on households. Housing Studies 17:107-123. 
Camina, M. and Iannone, P. (2014). Housing mix, school mix: barriers to success. Journal of Education Policy. 29(1), 19-43.

Graham, E., D. Manley, R. Hiscock, P. Boyle, and J. Doherty. 2009. Mixed housing tenures: is it good for social well-being? Urban Studies 46: 139-165.

Hamnett, C., and T. Butler. 2011. 'Geography Matters': the role distance plays in reproducing educational inequality in East London. Transactions of the Institute of British Geographers 36(4): 479-500.

Holme, J. 2002. Buying homes, buying schools: school choice and the social construction of school quality. Harvard Educational Review 72: 177-205.

Kamberelis, G., and G. Dimitriadis. 2005. Focus groups, strategic articulations of pedagogy, politics, and inquiry. In N. Denzin and Y. Lincoln, eds. The SAGE handbook of qualitative research. 3rd edition. London: Sage

Kearns, A., and M. Parkinson. 2001. 'The significance of neighbourhood'. Urban Studies 38: 2103-2110.

Lauder, H., and D. Hughes. 1990. Social inequalities and differences in school outcomes. New Zealand Journal of Educational Studies 25: 37-60.

Lipman, P. 2008. Mixed-income schools and housing: advancing the neoliberal urban agenda. Journal of Education Policy 23: 119-134.

Lupton, R., and R. Tunstall. 2008. Neighbourhood regeneration through mixed communities: a 'social justice dilemma'? Journal of Education Policy 23: 105-117. 
Camina, M. and Iannone, P. (2014). Housing mix, school mix: barriers to success. Journal of Education Policy. 29(1), 19-43.

Murie, A., and E. Ferrari. 2003. Reforming the Right to Buy in England. Birmingham: University of Birmingham, Centre for Urban and Regional Studies.

Noden, P., and A. West. 2009. Attainment gaps between the most deprived and advantaged schools. London: The Sutton Trust.

Norris, M. 2006. Developing, designing and managing mixed tenure estates: implementing planning gain legislation in the republic of Ireland. European Planning Studies 14: 199-218.

Reay, D., and H. Lucey. 2003. The Limits of 'Choice': Children and Inner City Schooling. Sociology 37: 121-142.

Rosenbaum, J., L. Reynolds, and S. DeLuca. 2002. How do places matter? The geography of opportunity, self-efficacy and a look inside the black box of residential mobility. Housing Studies 17: 71-82.

Rowlands, R., A.S. Murie, and A. J. Tice. 2006. More than tenure mix: developer and purchaser attitudes to new housing estates. Birmingham: University of Birmingham, Centre for Urban and Regional Studies.

Savage, M., G. Bagnall, and B. Longhurst. 2005. Globalization and belonging. London:Sage. 
Camina, M. and Iannone, P. (2014). Housing mix, school mix: barriers to success. Journal of Education Policy. 29(1), 19-43.

Savage, M., J. Barlow, P. Dickens, and T. Fielding. 1992. Property, Bureaucracy and Culture: Middle-class formation in contemporary Britain. London: Routledge.

Savage, M., and R. Burrows. 2007. The coming crisis in empirical sociology. Sociology 41: 885-899.

Silverman, E., R. Lupton, and A. Fenton. 2005. A good place for children? Attracting and retaining families in inner urban mixed communities. York: Joseph Rowntree Foundation.

Silverstone, R., ed. 1997. Visions of Suburbia. London: Routledge.

Singleton, A. 2007. Comparing classifications: some preliminary speculations on an appropriate scale for neighbourhood analysis with reference to geodemographic information systems. CASA Working Papers Series, No. 127. Retrieved from: www.casa.ucl.ac.uk/publications/workingPaperDetail.asp?ID=127

Skeggs, B. 2004. Class, self and culture. London: Routledge.

SQW Consulting. 2010. Local Authority Commissioning Pathfinders Study. Research Report DCSF-RR231. Retrieved from www.education.gov.uk/publications/standard/publicationDetail/Page1/DCSF-RR231 
Camina, M. and Iannone, P. (2014). Housing mix, school mix: barriers to success. Journal of Education Policy. 29(1), 19-43.

Thrupp, M., H. Lauder and T. Robinson. 2002. School composition and peer effects. International Journal of Educational Research 37: 483-504.

Thrupp, M., and R. Lupton. 2006. Taking school contexts more seriously: the social justice challenge. British Journal of Educational Studies 54: 308-328.

Tunstall, R. 2003. 'Mixed tenure' policy in the UK: privatization, pluralism or euphemism. Housing, Theory and Society 20: 133-59.

Turok, I., A. Kearns, and R. Goodlad. 1999. Social exclusion: in what sense a planning problem? Town Planning Review 70: 363-384.

Vincent, C., A. Braun, and S. Ball. 2010. Local links, local knowledge: choosing care settings and schools. British Educational Research Journal 36: 279-298.

Webber, R. 2004. The relative power of geodemographics vis a vis person and household level demographic variables as discriminators of consumer behaviour. CASA Working Paper Series No. 84. Retrieved from

www.casa.ucl.ac.uk/publications/workingPaperDetail.asp?ID $=84$

Webber, R. 2009. Response to 'The coming crisis in empirical sociology': An Outline of the Research Potential of Administrative and Transactional Data. Sociology 43: 169-178.

Webber, R., and T. Butler. 2007. Classifying pupils by where they live: how well does this predict variations in their GCSE results? Urban Studies 44: 1229-1253. 
Camina, M. and Iannone, P. (2014). Housing mix, school mix: barriers to success. Journal of Education Policy. 29(1), 19-43.

West, A., P. Noden, and A. Edge. 1998. Choices and expectations at primary and secondary stages in the state and private sectors. Educational Studies 24: 45-60.

West, A., and H. Pennell. 2000. Publishing school examination results in England: incentives and consequences. Educational Studies 26: 423-436.

Willms, J.D. 1992. Monitoring School Performance. London: Falmer Press.

Wood, M. 2003. A balancing act? Tenure diversification in Australia and the UK. Urban Policy and Research 21: 45-56.

Woods, P.A., C. Bagley, and R. Glatter. 1998. School choice and Competition: markets in the public interest. London: Routledge .

Yin, R. K. 2009. Case study research: design and methods. $4^{\text {th }}$ edition. London: Sage. 